\title{
Tax Incentive Policy for Geothermal Development: A Comparative Analysis in ASEAN
}

\author{
Mohammad Zainul Abidina,b*, Haula Rosdiana ${ }^{a}$, Roy Valiant Salomo ${ }^{a}$
}

${ }^{a}$ Faculty of Administrative Science, Universitas Indonesia, Indonesia

${ }^{b}$ Fiscal Policy Agency, Ministry of Finance, Indonesia

\begin{abstract}
This paper examines tax incentive policies in geothermal industries in ASEAN to better understand the development of geothermal industry investment in the ASEAN Member States (AMS) using a qualitative method. The results indicate that tax incentive policies have supported the investment climate and the development of geothermal industries in the AMS. Geothermal investments and production capacities in AMS have increased significantly. AMS that provide geothermal tax incentives include Indonesia, Lao PDR, the Philippines, Thailand and Vietnam. The performance of geothermal tax incentive policies is reflected in the level of utilization of geothermal potential, which is higher in states that provide greater tax incentives. The results also indicate that geothermal power plants in AMS use dry steam, flash and binary cycle technologies with flash plants being the most common. Results suggest that the future development of geothermal energy in AMS will be related to the tax incentive policy and investment climate in those states. Furthermore, the granting of various types of tax incentives should be focused on the initial investment in geothermal development. (O2020. CBIOREIJRED. All rights reserved
\end{abstract}

Keywords: Tax incentive, geothermal industry, power plant, investment, electricity

Article History: Received: June 13, 2019; Revised: November 24, 2019; Accepted: January 23, 2020; Available online: February 15,2020 How to Cite This Article: Abidin, M.Z., Rosdiana, H., and Salomo, R.V. (2020). Tax Incentive Policy for Geothermal Development: A Comparative Analysis in ASEAN. International Journal of Renewable Energy Development,9(1),53-62

https://doi.org/10.14710/ijred.9.1.53-62

\section{Introduction}

The ASEAN region has grown into one of the most attractive to global investors (ASEAN Secretariat, 2018). ASEAN Member States (AMS) offer attractive economic potential because they boast a large population base and rapid economic growth (Figure 1). In 2017, the total ASEAN population reached 642.1 million, most of whom are of productive age. In 2017, ASEAN economic growth reached $5.3 \%$, higher than the global economic growth rate of 3.7\% (International Monetary Fund, 2018).

The rising population and rapid development of the ASEAN economy are driving energy demand, which is expected to grow by 3\% per year from 2020. This region still relies heavily on fossil fuels, which collectively meet $80 \%$ of primary energy needs. By 2035 , ASEAN will rely increasingly on imported fuel. This creates a threat to energy security in AMS (Senderov \& Vorobev, 2018).

Attempts to strengthen energy security are being conducted through the development of renewable energy. One renewable energy source in ASEAN is geothermal energy, which can reduce dependence on fossil fuels and reduce the risk of price fluctuations, as well as decrease greenhouse gases and support environmental sustainability (Hasibuan \& Nazir, 2017). Compared with other renewable energy sources, geothermal energy has the advantage of a higher capacity factor (production capability), which is maintained by the influence of weather and climate (Nazari \& Porkhial, 2016).

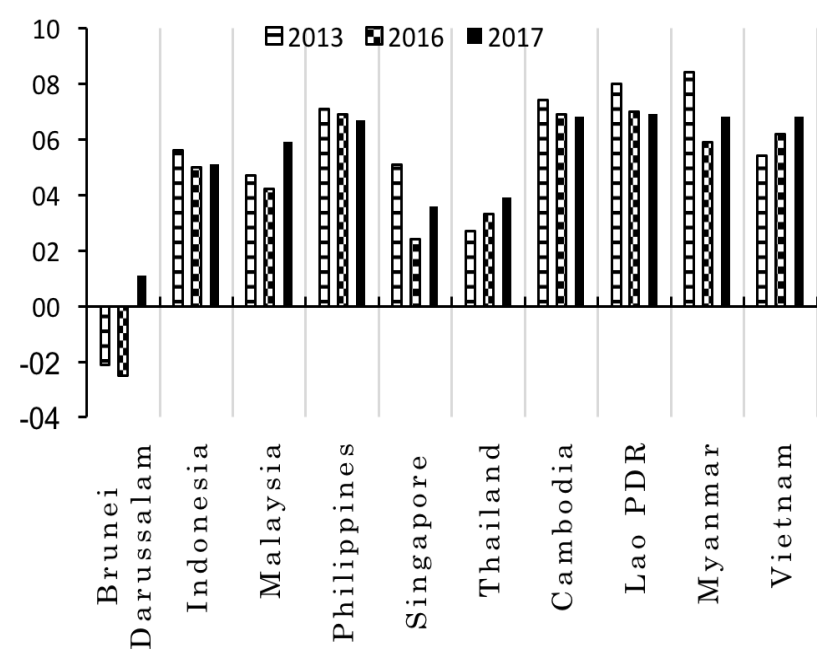

Fig. 1 ASEAN Member States Economic Growth at Constant Prices (ASEAN Secretariat, 2018)

\footnotetext{
* Corresponding author: abidinmz@gmail.com
} 
Geothermal development has considerable potential in AMS, which have developed a range of tax incentives. From an investor's perspective, tax incentives appeal to multinational companies because these companies implement tax optimization practices to identify the best locations for investment (Brodzka, 2013).

AMS have provided tax incentives to attract investors developing geothermal energy. However, geothermal development in AMS remains uneven. This study compares ASEAN tax incentive policies by identifying which AMS tax incentive policies are aligned with the characteristics of the geothermal industry. This analysis will provide information about which tax incentive policies are suitable for attracting investment in the developing geothermal industry.

\section{Tax Incentive and Geothermal Energy Overview}

\subsection{Definition of tax incentive}

Tax incentives are government grants awarded to certain companies or groups of companies that permit increased profits or a reduction in business costs/risks to attract investors in certain sectors (UNCTAD, 2000). Tax incentive policies reduce the cost of taxation, by simplifying levies in order to increase production capacity. The realization of economic efficiency facilitates the optimal production of outputs using the available resources (Rosdiana, 2008).

\subsection{The purpose of tax incentives}

Tax incentives are given to compensate for a poor investment climate (including the taxation system). In addition to states' motives to beat the competition in attracting foreign direct investment, the provision of tax incentives aims to support real economic gain (investment), encourage the accuracy of financial reporting (income) and encourage social benefits, such as improving education or retirement savings. Incentives can also be used to regulate producer behaviour as desired by the government (Klemm, 2010).

Tax incentives are granted to develop the economy by attracting global investors who are offered greater potential returns and fewer business risks. An important goal of various incentive packages is to influence investment decisions, by either offering higher investment returns or fewer investment risks (Chalk, 2001).

\subsection{Types of tax incentives}

Tax incentives can be divided into six types (Holland \& Vann, 1998; Fletcher, 2002), namely, tax holidays, investment allowances and tax credits, reduced corporate income tax rates, accelerated depreciation, exemptions from indirect taxes and export processing zones. Each type of tax incentive is selected according to the context (investment climate and characteristics) of the sector (Table 1).

\subsection{Definition of Geothermal Energy}

Active geothermal systems are indicated by the presence of manifestations on the Earth's surface such as hot springs/steam (Setyawan et al., 2016). Geothermal energy is stored in the form of hot water or steam in the bowels of the Earth (reservoir) at a depth of 1,500 to $2,500 \mathrm{~m}$. The hot steam can be used to generate electrical energy by drilling and flowing hot steam to drive turbines and rotate electricity generators (Figure 2). Furthermore, hot steam is injected back into the reservoir through reinjection wells to maintain fluid and heat balance, so that the geothermal system becomes sustainable (Wardani, 2017).

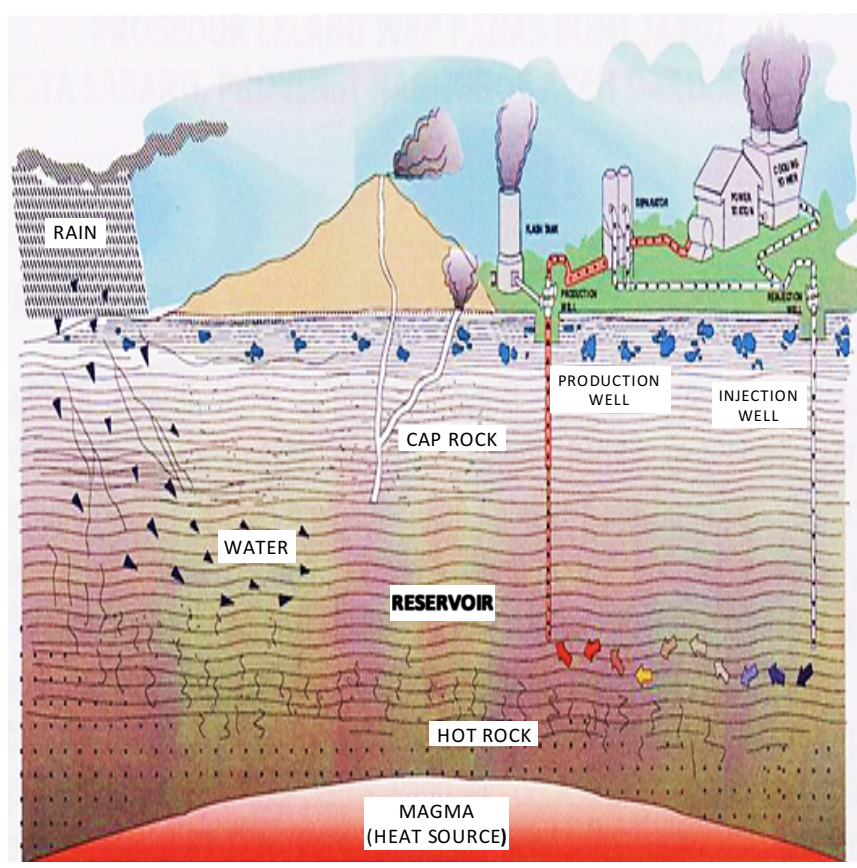

Fig. 2 Geothermal System (Directorate of Geothermal, 2018)

The initial stages of geothermal business activities include exploration and exploitation. Geothermal exploration takes 2-4 years. The exploration phase includes a preliminary survey and feasibility studies. Following good results, the process will continue to the exploitation stage. The exploitation phase includes the development of well drilling activities and the construction of field facilities including geothermal resource production operations (Muharti, undated).

Geothermal development is capital intensive, requires expertise and technology and is high risk (Muharti, undated), with different risks entailed at each stage. The later the development stage, the lower the risk. During the exploration phase, the first well drilling will reduce risk by $40 \%$ and the second well drilling will reduce the risk to $30 \%$. The third well drilling will further reduce the risk of development to only 20\% (Directorate of Geothermal, 2018).

\subsection{Roles of Geothermal Energy for Electrical Energy}

Geothermal energy has been used by power plants in Italy since 1913 and in New Zealand since 1958. Increasing demand for energy and rising oil prices in 1973 and 1979 encouraged countries to reduce their dependence on oil by utilising geothermal energy. At present, geothermal energy is being utilised by power plants in 24 countries (Kitz, 2016).

The development of geothermal power plants aims to create economic value in the long term while preserving the environment. In addition, these developments reduce greenhouse gas emissions, especially $\mathrm{CO}_{2}$ (carbon dioxide) generated by electricity plants (Kitz, 2016). 
Table 1

Advantages and Disadvantages of Tax Incentives by Type

\begin{tabular}{|c|c|c|}
\hline \multicolumn{2}{|r|}{ Advantages } & Disadvantages \\
\hline \multicolumn{3}{|r|}{ Reduced Corporate Income Tax Rates } \\
\hline 1) & Simpler tax administration & 1) More profitable large corporations still investing their capital without the incentive \\
\hline 2) & Easier to identify loss of potential & $\begin{array}{l}\text { 2) Increasing the risk of transfer pricing manipulation to divert most of the profits to } \\
\text { countries with lower tax rates }\end{array}$ \\
\hline & & 3) A windfall or an unexpected profit for an existing company \\
\hline & & 4) High possibility will not be given tax exemptions in the country of residence \\
\hline
\end{tabular}

\begin{tabular}{ll}
\hline & Tax Holidays \\
\hline 1) Simpler tax administration & 1) The same as a lower tax rate as above but with possibility of tax exemptions
\end{tabular}

2) Minimises taxpayers' interaction with tax officials (important in preventing corruption)

2) Attractive to short-term projects only

3) Encouraging tax avoidance by stopping investment activities at the end of the tax-free period and forming new companies to extend the tax-free period.

4) Distorting competition between new and established companies because new companies enjoy tax-free facilities

5) The difficult potential loss of tax revenue unless required by the Annual Tax Return report, but eliminates administrative simplicity.

1) Can only be given to certain 1) Encourages the purchase of new assets because they can be offset, which distorts the investments with the greatest benefits

Investment Allowances and Tax Credit

2) Easier to identify potential loss of tax 2 revenue

2) Can encourage tax avoidance if the company sells its old assets and then immediately repurchases them to obtain tax relief

3) Adds administrative burden

4) Can be detrimental to long-term investment if the rules regarding tax loss carried forward are not aligned

\section{Accelerated Depreciation}

1) Considered fair as all profits from 1) Greater administrative burden investments can be offset along with the provision of tax credit

2) Discrimination against long-term investments if the rules regarding tax loss carried forward are not aligned

2) Does not distort asset selection

3) Aligns company income tax with consumption tax to reduce the negative influence of income tax on investment

\section{Exemption from Indirect Taxes}

Taxpayers can avoid contact with tax 1) Value-Added Tax (VAT) exemption may not be appealing because the taxpayer can credit officials (important in preventing corruption) all the VAT that has been paid (input tax).

2) Prone to cause tax avoidance attempts.

Export Processing Zones

Minimises taxpayers' interaction with
tax officials (important to prevent
corruption)

(Fletcher, 2002)

\section{Method}

This study used a qualitative method. Secondary data were collected to examine tax incentive policies and the development of the geothermal industry, using literature review techniques.
The scope of this study covers a range of issues in tax policy and implementation, technology and the attainment of geothermal development goals, thus affording us an informed view of the prevailing geothermal situation in AMS. The comparison aimed to investigate the differences between the geothermal development situations in various AMS. 
Data for analysis were sourced from six out of a total of 10 AMS that have geothermal resources: Indonesia, Lao PDR, Myanmar, Thailand, the Philippines and Vietnam. Geothermal development data from each of these countries are also presented. Other AMS, such as Brunei Darussalam, Cambodia, Malaysia and Singapore, were excluded because they do not have geothermal resources (ASEAN Centre for Energy, 2018).

This study analysed the role of tax incentive policies in supporting the investment climate. Geothermal tax incentive policies from six AMS were taken from journal articles, conference proceedings, international institutions and industry studies, government records and reports, and online sources of information. The geothermal tax incentive policy for each AMS was classified according to the stages of geothermal development (Muharti, 2017).

The authors conducted a comparative study to obtain tax incentive policy information supporting geothermal development in each country. Comparisons of taxation practices related to investment activities and geothermal operations were made on the basis of four main indicators, namely, tax payment procedures, the time required to comply with taxes, the total tax and contribution rate and the postfiling index (World Bank, 2019).

The tax payment indicator reflects the amount of tax owed, the method and frequency of payment, the frequency of filing and the number of agencies involved in complying with tax obligations. The time indicator measured the time required to complete payment of corporate income tax, value-added tax or sales tax and labour taxes, including payroll taxes and social contributions. The total tax and contribution rate indicators measured the ratio of the amount of tax and mandatory contributions borne by the company as a share of profits. The post filing index refers to the administrative requirements following annual tax returns, such as compliance time for tax refunds, time taken to obtain tax refunds, time required to comply with tax corrections and time required to complete tax corrections (World Bank, 2019).

\section{Results and Discussion}

\subsection{Geothermal Potential in ASEAN}

AMS are located in the ring of fire, a geological term that describes the volcanic lines between India and the Pacific Ocean. This area consists of multiple volcanoes with potential geothermal resources. AMS have a geothermal potential of $35 \mathrm{GW}$ or around $48 \%$ of the world's total geothermal resources. The states with abundant geothermal resources are Indonesia, the Philippines, Lao PDR, Myanmar, Thailand and Vietnam (Richter, 2019).

Geothermal utilisation was first carried out in the 1960s near Mount Mayon in the Philippines. In 1980, Indonesia succeeded in building its first geothermal power plant project in Kamojang, West Java. In 1989, Thailand built its first geothermal power plant.

\subsection{Geothermal Development of ASEAN Member States}

AMS have the geothermal potential of $34,049 \mathrm{MW}$, mostly in Indonesia (84.9\%) and the Philippines (12.7\%). In 2017, the maximum total installed capacity in Indonesia was at $1,949.5 \mathrm{MW}(6.74 \%$ of its potential) and at 1,927.9 MW in the Philippines (44.47\% of its potential). Table 2 shows the potential and geothermal installed capacity in ASEAN (ASEAN Centre for Energy, 2018).

Table 2

Geothermal Potential and Installed Capacity of AMS

\begin{tabular}{cccc}
\hline State & $\begin{array}{c}\text { Geothermal } \\
\text { Potential } \\
\text { (MW) }\end{array}$ & $\begin{array}{c}\text { Installed } \\
\text { Capacity } \\
\text { (MW) }\end{array}$ & $\begin{array}{c}\text { Utilisation of } \\
\text { Potential (\%) }\end{array}$ \\
\hline Indonesia & 28,910 & $1,949.5$ & 6.74 \\
Lao PDR & 59 & 0 & 0 \\
Myanmar & 400 & 0 & 0 \\
Philippines & 4,335 & $1,927.9$ & 44.47 \\
Thailand & 5 & 0.3 & 6 \\
Vietnam & 340 & 0 & 0 \\
Total & 34,049 & $3,877.7$ & 11.38 \\
\hline
\end{tabular}

(ASEAN Centre for Energy, 2018)

Figure 3 shows the development of the ASEAN geothermal industry from 2007 to 2017. In 2007, the total installed geothermal capacity was $2.93 \mathrm{GW}$. By 2017 , the total installed geothermal capacity had reached $3.87 \mathrm{GW}$ or $11.38 \%$ of the total geothermal potential in ASEAN countries (ASEAN Centre for Energy, 2018).

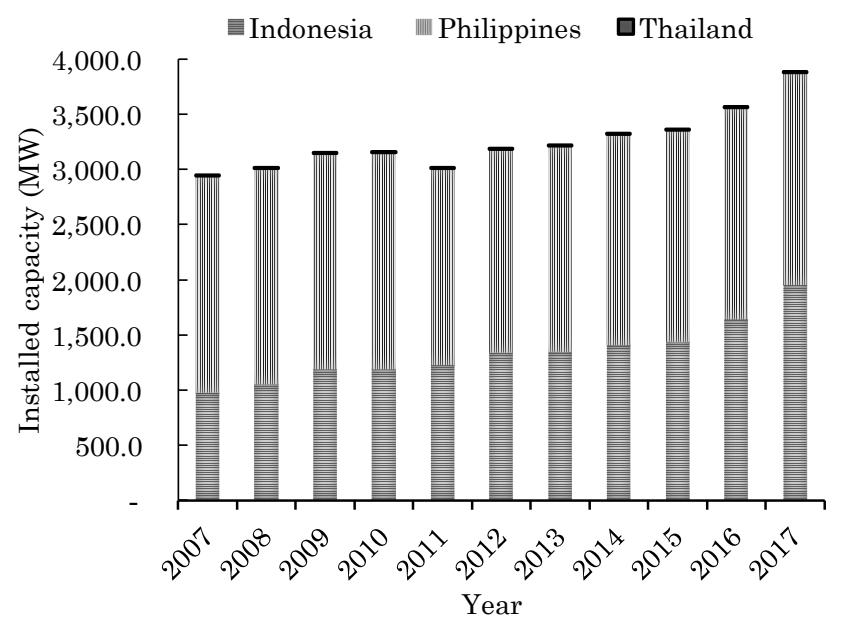

Fig. 3 Installed Geothermal Power Capacity in AMS from 2007 to 2017 (ASEAN Centre for Energy, 2018)

\subsection{Tax Incentive Policies in ASEAN Member States}

AMS issued geothermal sector policies a few decades ago. The Philippines and Indonesia have included geothermal resources as part of their renewable energy target policies. The Philippines has passed a law promoting the exploration and development of geothermal resources back in 1978 and has a target geothermal power capacity of $3.4 \mathrm{GW}$ by 2030 . The Indonesian government has issued a geothermal regulation through a Presidential Decree back in 1981 and has a target of $7.1 \mathrm{GW}$ installed geothermal power capacity by 2025 .

Tax incentive policies help develop the geothermal industry. The provision of tax incentives is designed to achieve energy supply targets through enhanced geothermal industry development. The geothermal development investment climate is therefore enhanced 
through tax incentive instruments.

Geothermal tax incentive policies are implemented throughout the distinct stages of each project. Policies relevant to the exploration-installation and exploitation/operation stages include tax incentives. In addition to these types of tax incentives, AMS also permit investors to obtain more income through policies allowing the accelerated depreciation of assets and the provision of long periods of operations (15-30 years).

1) Indonesia: Indonesia has about $40 \%$ of the world's geothermal potential, but only $6.74 \%$ is currently being used. The development of the country's geothermal production capacity has advanced during the period 20102018, which amounted to $415 \mathrm{MW}$. At present, less than $3 \%$ of total domestic power generation capacity derives from geothermal energy. Indonesia has targeted an increase in this share by adding $5 \mathrm{GW}$ of geothermal power capacity by 2022 (Pambudi, 2018). The fastest development occurred from 1990 to 1999. During this period, Indonesia recorded an increase in geothermal production capacity of 798.5 MW (Fronda et al., 2015). Most geothermal plants in Indonesia utilise flash steam technology (the Ministry of National Development Planning, 2014).

Table 3

\begin{tabular}{cc} 
Summary of Indonesia Electricity & \\
\hline Description & Statistics \\
\hline Total land area & $1,913,579 \mathrm{~km}^{2}$ \\
Population & 258.7 million people \\
Gross Domestic Product & USD 931,216 million \\
Annual GDP growth & $5.0 \%$ \\
Electricity ratio & $91 \%$ \\
Average electricity consumption & $792.5 \mathrm{kWh}$ per capita \\
Electricity tariff & $18 \mathrm{cent} \mathrm{USD} / \mathrm{kWh}$ \\
Renewable energy target & $46,307 \mathrm{MW}(2025)$ \\
\hline (ASEAN Centre for Energy, 2018) &
\end{tabular}

The acceleration of Indonesia's economic performance is driving increased electricity demand (Table 3). To increase the electrification ratio, Indonesia needs to increase energy productivity and attract investment in electricity generation through a tax incentive policy.

In 2019, Indonesia ranked $73^{\text {rd }}$ in ease of doing business and $112^{\text {th }}$ in ease of paying taxes (World Bank, 2019). The assessment of ease of paying taxes consists of four main indicators, namely, the procedure for paying taxes, the time required to meet tax obligations, the tax percentage on company profits and the postfiling index. Indonesia has a 68.82 postfiling index and a $30.1 \%$ tax rate on profits. Tax payment procedures indicate 43 tax payments per year and 207.5 hours are required to carry out obligations ranging from preparing reports to paying taxes. The number of tax payments in Indonesia is the highest among AMS. However, the time period provided for taxpayers to settle tax obligations in Indonesia is better than that in other AMS.

Indonesia has tried to attract investment in the geothermal sector by issuing tax incentive policies (Setiawan, 2014). The tax incentives include tax holidays (corporate income tax exemption for 5 to 15 years), investment allowances and tax credits (import duty facility, a reduction in net income by a percentage of the amount invested and extension of tax loss carried forward) and accelerated depreciation. In addition, Indonesia provides special tax relief for investors in the form of dividend incentives (a reduction of income tax on dividends).

2) Lao PDR: Lao PDR has a geothermal power plant potential of $59 \mathrm{MW}$. However, investment in the geothermal industry has not developed (Mekong Energy and Environment Partnership, 2011).

Lao PDR has achieved economic growth above the AMS average, which has increased electricity demand (Table 4). Lao PDR is now trying to increase energy productivity and attract energy investment through tax incentives to improve the electrification ratio.

Table 4

Summary of Lao PDR Electricity

\begin{tabular}{cc}
\hline Description & Statistics \\
\hline Total land area & $236,800 \mathrm{~km}^{2}$ \\
Population & 6.6 million people \\
Gross Domestic Product & USD 15,903 million \\
Annual GDP growth & $7.0 \%$ \\
Electricity ratio & $93 \%$ \\
Average electricity consumption & $530.6 \mathrm{kWh}$ per capita \\
Electricity tariff & $8.69 \mathrm{cent} \mathrm{USD} / \mathrm{kWh}$ \\
Renewable energy target & $951 \mathrm{MW}(2025)$ \\
\hline (ASEAN Centre for Energy, 2018) &
\end{tabular}

In 2019, Lao PDR ranked $141^{\text {st }}$ in ease of doing business and $156^{\text {th }}$ in ease of paying taxes (World Bank, 2019). Lao PDR obtained a tax payment score of 54.22, a postfiling index of 18.57 and a percentage tax burden on profits of $24.1 \%$. Tax payment procedures require 35 tax payments per year and 362 hours are required to carry out obligations ranging from preparing reports to paying taxes annually.

Lao PDR provides tax incentives to attract investment in renewable energy, including the geothermal industry. Lao PDR's tax incentive policies include tax holidays (7 year corporate income tax holidays (ITH)), investment allowances and tax credits (exemption from import duties, taxes on raw materials and capital equipment), reduced corporate income tax rates (reduced tax rates by negotiation) and $10 \%$ personal income tax rate for expatriate employees.

3) Myanmar: Myanmar has a geothermal energy potential of $126 \mathrm{MW}$, which could be developed into a power plant. There are 93 potential locations for commercial geothermal-based electricity production (Asian Development Bank, 2016). At present, Myanmar is beginning to develop its geothermal potential by conducting assessments and testing at around 43 sites (Tun, 2019).

Myanmar has the lowest electricity tariff of all AMS. However, many residents have not yet received electricity services (Table 5). Myanmar has installed a renewable energy capacity of 3,204 MW (2014).

In 2019, Myanmar ranked $171^{\text {st }}$ in ease of doing business and $125^{\text {th }}$ in ease of paying taxes (World Bank, 2019). Myanmar received paying taxes score of 63.94 , a postfiling index of 45.54 and a percentage of the tax burden on profits of $31.2 \%$. Indicators report 31 tax 
payments are required per year and 282 hours are required to fulfil obligations ranging from preparing reports to paying taxes. Myanmar does not have any tax incentive policies to attract investment in the geothermal industry.

Table 5

Summary of Myanmar Electricity

\begin{tabular}{cc}
\hline Description & Statistics \\
\hline Total land area & $676,577 \mathrm{~km}^{2}$ \\
Population & 52.9 million people \\
Gross Domestic Product & USD 68,636 million \\
Annual GDP growth & $5.7 \%$ \\
Electricity ratio & $33 \%$ \\
Average electricity consumption & $215.3 \mathrm{kWh}$ per capita \\
Electricity tariff & 5 cent USD $/ \mathrm{kWh}$ \\
Renewable energy target & $472 \mathrm{MW}(2016)$ \\
\hline (ASEAN Centre for Energy, 2018)
\end{tabular}

4) The Philippines: The Philippines is the third largest geothermal energy producer in the world. The fastest increase in geothermal production capacity occurred from 1990 to 1999. During this period, the Philippines recorded an increase in production capacity of 1,021 MW. In 2007, geothermal production capacity reached 2,027 MW or $46.7 \%$ of the total geothermal energy potential of the Philippines (Fronda et al., 2015). Geothermal plants in the Philippines utilise flash steam and binary cycle technologies (Moon \& Zarrouk, 2012).

\section{Table 6}

Summary of the Philippines Electricity

\begin{tabular}{cc}
\hline Description & Statistics \\
\hline Total land area & $300,000 \mathrm{~km}^{2}$ \\
Population & 103.2 million people \\
Gross Domestic Product & USD 311,452 million \\
Annual GDP growth & $6.9 \%$ \\
Electricity ratio & $89 \%$ \\
Average electricity consumption & $667.6 \mathrm{kWh}$ per capita \\
Electricity tariff & $16 \mathrm{cent} \mathrm{USD} / \mathrm{kWh}$ \\
Renewable energy target & $15,236 \mathrm{MW}(2030)$ \\
\hline (ASEAN Centre for Energy, 2018) &
\end{tabular}

The Philippines is the country with the second largest population in the AMS, with accelerated economic growth driving increased electricity demand (Table 6). The Philippines has issued a tax incentive policy to enhance energy productivity and attract the relevant investment.

In 2019, the Philippines ranked $113^{\text {th }}$ in ease of doing business and $105^{\text {th }}$ in ease of paying taxes (World Bank, 2019). The Philippines obtained a paying taxes score of 71.80, postfiling index of 50.00 and a percentage of tax burden on profits of $42.9 \%$. Indicators report 14 tax payments per year are required and 181 hours are required to fulfil obligations ranging from preparing reports to paying taxes.

The Philippines has issued tax incentive policies to attract investment in the geothermal field. These include tax holidays (7 year ITH), investment allowances and tax credits (loss carry-over; tax exemption on carbon credits, exemption from Universal Charge and $100 \%$ tax credit on domestic capital equipment and services), reduced corporate income tax rates $(10 \%$ corporate income tax rate after ITH and $1.5 \%$ special real property tax rates on equipment and machinery), accelerated depreciation and exemptions from indirect taxes ( $0 \%$ value-added tax).

5) Thailand: Thailand has the geothermal potential for power plants of $59 \mathrm{MW}$. Geothermal investigations in Thailand began in 1946 and subsequently, more than 90 hot springs were mapped (Wood \& Singharajwarapan, 2014). A small binary cycle power plant (0.3 MW) was installed in Fang, at the north end, near the border with Myanmar. Since its commissioning in December 1989, the only Thailand geothermal power plant has been operating successfully at $85 \%-90 \%$ capacity (Raksaskulwong, 2015). The geothermal plant in Thailand utilises binary cycle technology (Moon \& Zarrouk, 2012).

Table 7

Summary of Thailand Electricity

\begin{tabular}{cc}
\hline Description & Statistics \\
\hline Total land area & $513,119 \mathrm{~km}^{2}$ \\
Population & 67.4 million people \\
Gross Domestic Product & USD 407,048 million \\
Annual GDP growth & $3.2 \%$ \\
Electricity ratio & $100 \%$ \\
Average electricity consumption & $2,605.7 \mathrm{kWh}$ per capita \\
Electricity tariff & 11 cent USD $/ \mathrm{kWh}$ \\
Renewable energy target & $19,684 \mathrm{MW}(2036)$ \\
\hline (ASEAN Centre for Energy, 2018) &
\end{tabular}

Thailand has sufficient electricity for its residents (Table 7). However, Thailand still provides tax incentives for electricity development.

In 2019, Thailand ranked $26^{\text {th }}$ in ease of doing business and $67^{\text {th }}$ in ease of paying taxes (World Bank, 2019). Thailand obtained a paying taxes score of 77.72 , a postfiling index of 73.41 and a percentage of tax burden on profits of $29.5 \%$. Indicators report 21 tax payments per year are required and 229 hours are required to fulfil tax obligations, from the preparation of reports to tax payments.

Thailand issued a tax incentive policy in an attempt to attract investment, including in the geothermal sector. Tax incentive policies include tax holidays (income tax exemptions for 8 years on earnings), investment allowances and tax credits (reduction of import duties on essential materials and machinery, special corporate tax allowances and reduction in income tax) and reduced corporate income tax rates (a $50 \%$ reduction in the corporate income tax rate).

6) Vietnam: Vietnam has the geothermal potential to generate $131 \mathrm{MW}$ of electricity. Exploration and evaluation of geothermal resources indicate there are 30 potential electricity-generating locations with a total capacity of $340 \mathrm{MW}$. However, there are no geothermal power plants at present. Thermal reserves produce $1.16 \%$ of the total national electricity production output (Asian Development Bank \& Asian Development Bank Institute, 2016). 
Table 8

Summary of Vietnam Electricity

\begin{tabular}{cc}
\hline Description & Statistics \\
\hline Total land area & $330,951 \mathrm{~km}^{2}$ \\
Population & 92.7 million people \\
Gross Domestic Product & USD 198,196 million \\
Annual GDP growth & $6.7 \%$ \\
Electricity ratio & $99 \%$ \\
Average electricity consumption & $1,564 \mathrm{kWh}$ per capita \\
Electricity tariff & 7 cent USD/kWh \\
Renewable energy target & $45,800 \mathrm{MW}(2030)$ \\
\hline (ASEAN Centre for Energy, 2018)
\end{tabular}

Vietnam is the third most populous country of the AMS. The large population and acceleration of economic growth has driven huge electricity demand (Table 8). To increase energy productivity and attract investment, Vietnam has issued tax incentive policies.

In 2019 , Vietnam ranked $68^{\text {th }}$ in ease of doing business and $86^{\text {th }}$ in ease of paying taxes (World Bank, 2019). Vietnam obtained a paying taxes score of 62.87 , a postfiling index of 49.08 and a percentage of tax burden on profits of $37.8 \%$. Indicators report 10 tax payments per year are required and 498 hours are required to fulfil tax obligations.

Vietnam has issued tax incentive policies to attract investments in renewable energy, including geothermal energy. These include tax holidays (4-year corporate income tax exemption), investment allowances and tax credits (exemption from import tax on imported input or semi-finished products for project operations, other incentives on income tax and import duties on the amount of electricity generated from Clean Development Mechanism projects), reduced corporate income tax rates (10\% corporate income tax rate for 9 years rather than the normal tax rate of 20\%) and accelerated asset depreciation.

\subsection{Comparison of ASEAN Geothermal Tax Incentive Policies}

AMS offer a range of tax incentives to attract geothermal investment. However, different countries provide different types of tax incentives (Table 9). The Philippines provides the greatest range of geothermal tax incentives among ASEAN countries. Meanwhile, Myanmar has not issued any tax incentive policies to encourage the development of the geothermal industry but has issued tax incentives to encourage renewable energy development.

The greater the potential for geothermal development, the greater the range of tax incentives provided to attract investment in the geothermal industry. This indicates that ASEAN governments are keen to utilise geothermal potential to support their national energy supply.

Thailand provides tax incentives in the form of tax exemptions during the geothermal explorationinstallation and exploitation/operation phases. However, the types of tax incentives offered (tax exemptions) are not as generous as those provided by the Philippines and Indonesia.

\subsection{ASEAN Tax Incentive Policies and Characteristics of the Geothermal Industry}

AMS provide incentives to reduce high installation costs to provide attractive economic value to investors. The appropriate tax incentive policies support geothermal investment (Wahjosoedibjo \& Hasan, 2018), namely, tax holidays for the first 8-10 years, accelerated depreciation to 5-8 years, investment allowances for 5 years and exemptions from indirect taxes.

Figure 4 shows the average costs of renewable energy generation in AMS. The largest components, contributing more than $75 \%$ to the total cost of geothermal power plants, include equipment costs, civil works, design, engineering and project management. Nearly $10 \%$ of the total installation costs consist of the financial costs incurred during construction, because building geothermal power plants generally takes a long time. Of the total investment, $6.7 \%$ is required for exploration, as well as land acquisition and development. Transportation, insurance, installation and commissioning fees and network connections account for $4.5 \%$, whereas $3.8 \%$ of the total costs cover administration (ASEAN Centre for Energy, 2018).

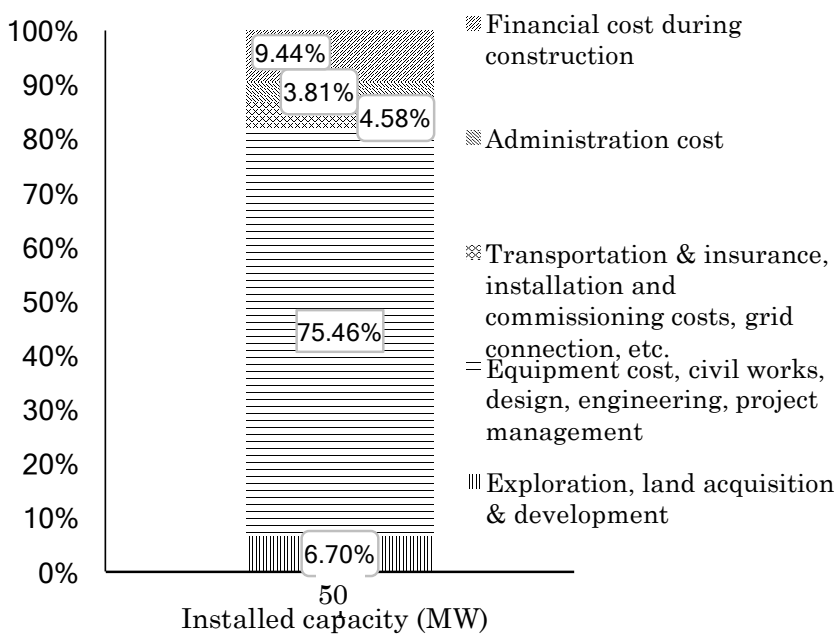

Fig. 4 Cost Breakdown of a Geothermal Power Plant (ASEAN Centre for Energy, 2018)

The competitiveness of geothermal energy in Indonesia and the Philippines is equivalent to that of the US. The average operating/exploitation costs for all plants are $5.84 \%$ of the total capital expenditure. This is in the same range as the cost of operating and the exploitation of geothermal power plants as reported by the Department of Energy, the United States of America.

From the perspective of investors, AMS have a different appeal in the geothermal sector. Geothermal investors prioritise Indonesia, the Philippines and Vietnam. Furthermore, there are states that are the priority of geothermal investors, namely, Thailand, Myanmar and Lao PDR, respectively (PwC, 2018).

Tax incentive policies will succeed if the increase in income from investment and ensuing social benefits outweighs the revenue lost due to the indirect costs due to tax incentive policies (James, 2014). In addition, the formulation of tax incentive policies should consider the country's context (Table 10). 
Citation: Abidin, M.Z., Rosdiana, H., and Salomo, R.V. (2020). Tax Incentive Policy for Geothermal Development: A Comparative Analysis in ASEAN. Int. Journal of Renewable Energy Development,9(1), 53-62, doi.org/10.14710/ijred.9.1.53-62

$\mathrm{P}$ a g e 160

Table 9

Geothermal Development Tax Incentive Policies in ASEAN

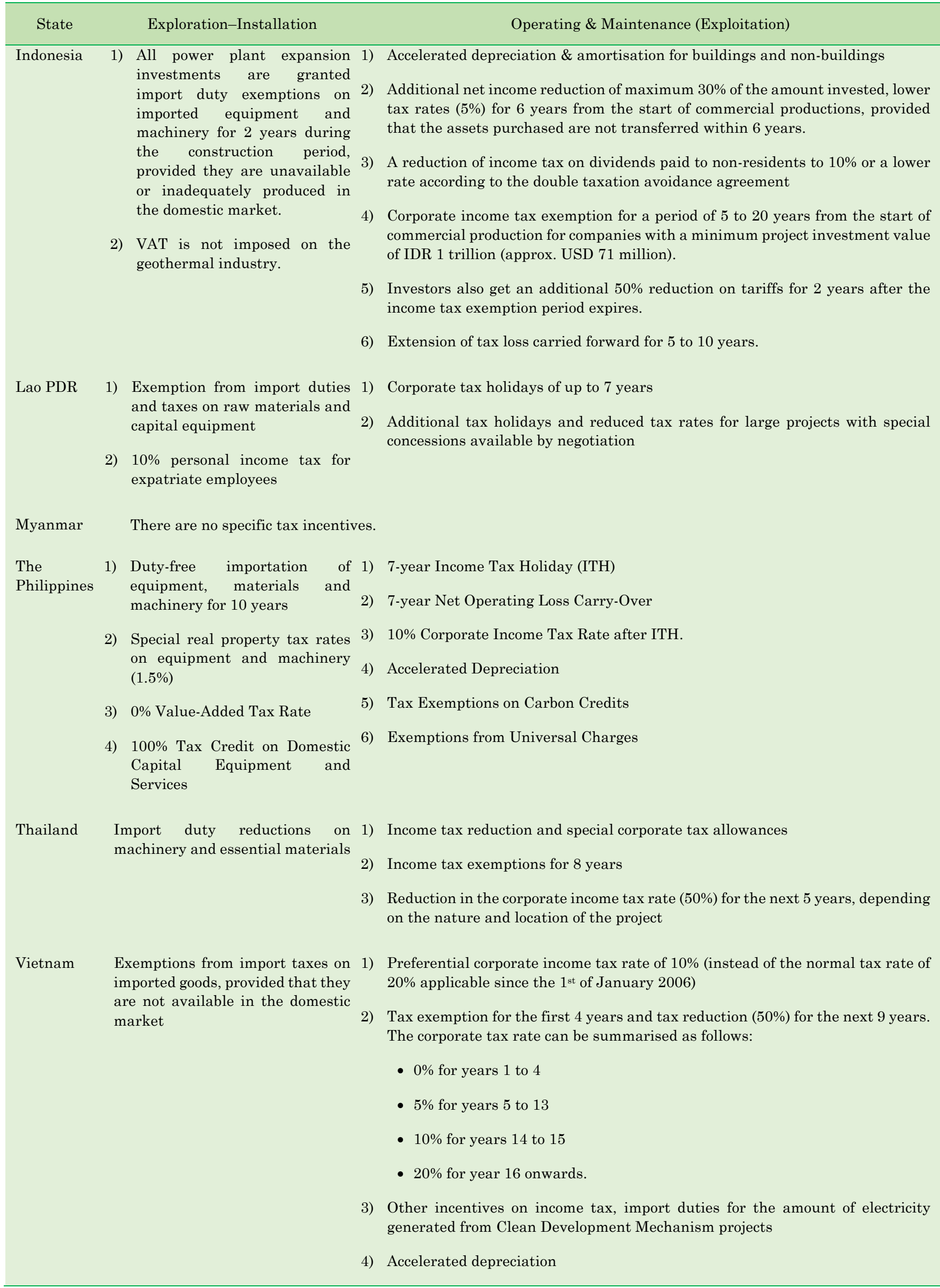


Table 10

Scenario-Based Tax Incentive Policy

State Condition

States with a poor investment climate

tates facing taxation competition
Short-Term Policy

Investment incentives are ineffective and tax revenues are reduced. Tax receipts should be used for public welfare. Reforms should include improvements to the taxation system.

Incentives can be used to maintain investment appeal towards neighbouring states that offer investment incentives.

States planning to diversify their economy

Each state can use incentives related to investment growth (investment allowance, accelerated depreciation, etc.) but only for a certain period based on priority sectors that align with Foreign Direct Investment (FDI) competitiveness.
States should enter into joint agreements to prevent detrimental tax competition. States should do more to highlight substantive advantages, such as labour, expertise and infrastructure.

Broader industrial policy strategies must be continued, including a focus on targeted sectors and investment promotion.

Barriers should be overcome by plans to exploit these natural resources, land access and infrastructure.
A state with unique value propositions (natural beauty, natural resources)
Investment incentives in general to attract investment that exploits these advantages will undermine tax revenue, except as an incentive at the beginning of the investment.
The states should fix investment barriers and focus on simplifying the overall investment process.

(James, 2014)

In the context of each country, geothermal potential is a natural resource, making it a unique value proposition for a nation state. On the basis of Table 10, tax incentive policies for the geothermal industry can be divided into short-term and long-term scenarios. In the short- term, tax incentives must be provided during the initial investment period, which is the exploration-installation stage. In the long run, tax incentive policies are not relevant to the characteristics of investment developments in the geothermal industry.

\section{Conclusions}

The results of the study indicate that tax incentive policies have supported the investment climate and geothermal industry development in AMS. Geothermal investments and production capacities in AMS have increased significantly, especially in Indonesia and the Philippines. AMS that provide geothermal tax incentives are Indonesia, Lao PDR, the Philippines, Thailand and Vietnam. The performance of geothermal tax incentive policies is reflected in the utilisation of geothermal potential, which is higher in states that provide more tax incentives.

The results also indicated that AMS geothermal power plants use dry steam, flash and binary cycle technologies. Flash plants are the most common in AMS. It is likely that the future development of geothermal energy in AMS will depend on the tax incentive policies and investment climates in those states. Furthermore, the range of tax incentives granted should focus on the initial investment activities in geothermal development.

\section{Acknowledgements}

We are grateful to the reviewers for their feedback and constructive comments. We thank the Ministry of Finance of the Republic of Indonesia for the support in completing this research.

\section{References}

ASEAN Centre for Energy (2018) Levelised Costs of Electricity (LCOE) for Selected Renewable Energy Technologies in The ASEAN Member States II. Jakarta: ASEAN Centre for Energy (ACE) \& Deutsche Gesellschaft für Internationale Zusammenarbeit (GIZ) GmbH.

ASEAN Centre for Energy Team (2016) ASEAN Renewable Energy Sub-Sector Network. Deutsche Gesellschaft fur Internationale Zusammenarbeit (GIZ) GmbH \& ASEAN Centre for Energy (under the Renewable Energy Support Programme for ASEAN).

ASEAN Secretariat (2018) ASEAN Statistical Highlights 2018. Community Relations Division-The ASEAN Secretariat, Jakarta.

Asian Development Bank \& Asian Development Bank Institute (2016) Viet Nam: Energy Sector Assessment, Strategy, and Road Map. Mandaluyong City, Philippines, Asian Development Bank.

Asian Development Bank (2015) Renewable Energy Developments and Potential in The Greater Mekong Subregion. Mandaluyong, Manila, Philippines.

Asian Development Bank (2016) Myanmar Energy Sector Assessment, Strategy, and Road Map, Mandaluyong, Manila, Philippines.

Brodzka A. (2013) Tax Incentives in Emerging Economies. Business Systems and Economics, 3(1), 26-36.

Chalk N. A. (2001) Tax Incentives in The Philippines: A Regional Perspective. IMF Working Paper, WP/01/181.

Directorate of Geothermal (2018) Doing Business in Geothermal. Jakarta: Kementerian Energi dan Sumber Daya Mineral.

Energy and Environment Partnership Mekong (2011). Renewable Energy Development Strategy in Lao PDR. Article at http://www.eepmekong.org/index.php/resources/countryreports/laos/57-laos-06/file. Accessed on 5 April 2019.

Fletcher K (2002) Tax Incentives in Cambodia, Lao PDR and Vietnam. The Paper Prepared for the IMF Conference on Foreign Direct Investment: Opportunities and Challenges for Cambodia, Lao PDR and Vietnam Hanoi, Vietnam, August 16-17, 2002.

Fronda A.D., Marasigan M.C. and Lazaro V.S. (2015) Geothermal Development in The Philippines: The Country Update, Proceedings World Geothermal Congress Melbourne, Australia. 
Hasibuan S. \& Nazir N. (2017) The Development Strategy of Sustainable Bioethanol Industry on Iconic Sumba Island, Eastern Indonesia. International Journal on Advanced Science Engineering Information Technology, 7(1), 276283.

Holland D. \& Vann R.J. (1998) Income Tax Incentives for Investment in Victor Thuronyi, Ed., Tax Law Design and Drafting Volume 2, Washington DC: International Monetary Fund.

Moon H. \& Zarrouk S.J. (2012) Efficiency of Geothermal Power Plants: A Worldwide Review. Proceedings of New Zealand Geothermal Workshop 2012 Auckland, New Zealand, 1921 November 2015, 1-13.

Intelligent Energy Systems and Mekong Economics Ltd (2016) Alternatives for Power Generation in the Greater Mekong Subregion. Power Sector Vision for the Greater Mekong Subregion, Volume 1.

International Monetary Fund (2018) IMD Data Mapper: World Economic Outlook. https://www.imf.org/external/datamapper/NGDP_RPCH @WEO/WEOWORLD/SEQ. Accessed on 5 April 2019.

James S. (2014) Effectiveness of Tax and Non-Tax Incentives and Investments: Evidence and Policy Implications. Investment Climate Advisory Services, World Bank Group. Available at SSRN: http://dx.doi.org/10.2139/ssrn.2401905. Accessed on 27 februari 2018

Kitz K. (2016) Geothermal Power Generation, 2nd ed., D. Yogi Goswami and Frank Kreith, Ed. Florida, USA: Taylor and Francis Group.

Klemm A. (2010) Causes, Benefits, and Risks of Business Tax Incentives. International Tax and Public Finance, 17, 315-336.

Ministry of National Development Planning (2014) Geothermal Handbook for Indonesia. Jakarta, Ministry of National Development Planning.

Muharti A. (2017). Tantangan Kembangkan 7.000 MW Energi Panas Bumi. Article at http://www.migasreview.com/post/1468291875/tantanga n-kembangkan-7-000-mw-energi-panasbumi.html. Accessed on 1 March 2019.

Nazari, N. and Porkhial, S. (2016). Energetic and Exergetic Improvement of Geothermal Single Flash Cycle. Int. Journal of Renewable Energy Development, 5(2),129-138. http://dx.doi.org/10.14710/ijred.5.2.129-138. Accessed on 15 October 2018.

OECD (2017) Investment framework for green growth in Lao PDR in OECD Investment Policy Reviews: Lao PDR, OECD Publishing, Paris, 237-264.

Pambudi N. A. (2018) Geothermal Power Generation in Indonesia, a Country within the Ring of Fire: Current Status, Future Development and Policy Renewable and Sustainable Energy Reviews, 81, p2893-2901.

PwC (2018) Alternating Currents: Indonesian Power Industry Survey 2018. The Report 2nd Edition. Asosiasi Produsen Listrik Swasta Indonesia, Jakarta.
Raksaskulwong M. (2015) Update on Geothermal Utilizations in Thailand. Proceedings of World Geothermal Congress 2015 Melbourne, Australia, 19-25 April 2015, 1-8.

Richter A. (2019) Report Highlights Competitiveness of Geothermal Energy in The ASEAN Region, http://www.thinkgeoenergy.com/report-highlightscompetitiveness-of-geothermal-energy-in-the-ASEANregion/. Accessed on 1 April 2019.

Rosdiana H. (2008) Rekonstruksi Konsepsi Supply Side Tax Policy. Jurnal Ilmu Administrasi dan Organisasi, Bisnis \& Birokrasi, vol. 15, no. 1, 202-205.

Senderov S. \& Vorobev S. (2018) Ensuring Energy Security in ASEAN Countries: Current Trends and Major Challenges. ASEAN Economic Community (AEC); Proceedings of 10th International Conference on Asian Energy Cooperation (AEC 2017).

Setiawan H. (2014) Geothermal Energy Development in Indonesia: Progress, Challenges and Prospect. International Journal on Advanced Science Engineering Information Technology, 4(4), 20-25.

Setyawan, A., Triahadini, A., Yuliananto, Y., Aribowo, Y., and Widiarso, D.A. (2016) Subsurface Structure and Fluid Flow Analyses Using Geophysical Methods in Geothermal Manifestation Area of Paguyangan, Brebes, Central Java. Int. Journal of Renewable Energy Development, 5(3), 171177. $\quad \mathrm{http}: / / \mathrm{dx}$.doi.org/10.14710/ijred.5.3.171-177. Accessed on 14 October 2018

Tapparan E.M.D. (2017) Indonesian Renewable Energy Policy and Investment Opportunities. Asia Clean Energy Forum 2017, The Transformative Role of Renewables in Southeast Asia, International Renewable Energy Agency and ASEAN Centre for Energy Manila, 6th June 2017.

Tun M. M. (2019) An Overview of Renewable Energy Sources and Their Energy Potential for Sustainable Development in Myanmar. European Journal of Sustainable Development Research, 3(1), 1-13.

UNCTAD (2000) Tax Incentives and Foreign Direct Investment: A Global Survey. ASIT Advisory Studies No. 16, Geneva, United Nations.

Wahjosoedibjo A.S. \& Hasan M. (2018) Indonesia's Geothermal Development: Where Is It Going? Proceedings of 43rd Workshop on Geothermal Reservoir Engineering Stanford University, Stanford, California, February 12$14,1-12$.

Wardani R. (2017) Energi Panas Bumi Ramah Terhadap Lingkungan Sekitar. Article at http://ebtke.esdm.go.id/post/2017/08/22/1733/energi.pana s.bumi.ramah.terhadap.lingkungan.sekitar. Accessed on 3 November 2017.

Wood S.H. \& Singharajwarapan F.S. (2014) Geothermal Systems of Northern Thailand and Their Association with Faults Active During the Quaternary. GRC Transactions, 38, 607-616.

World Bank (2019) Doing Business 2019. The Report 16th Edition, Washington D.C.: The World Bank Group.

World Energy Council (2010) 2010 Survey of Energy Resources. London, United Kingdom, World Energy Council 